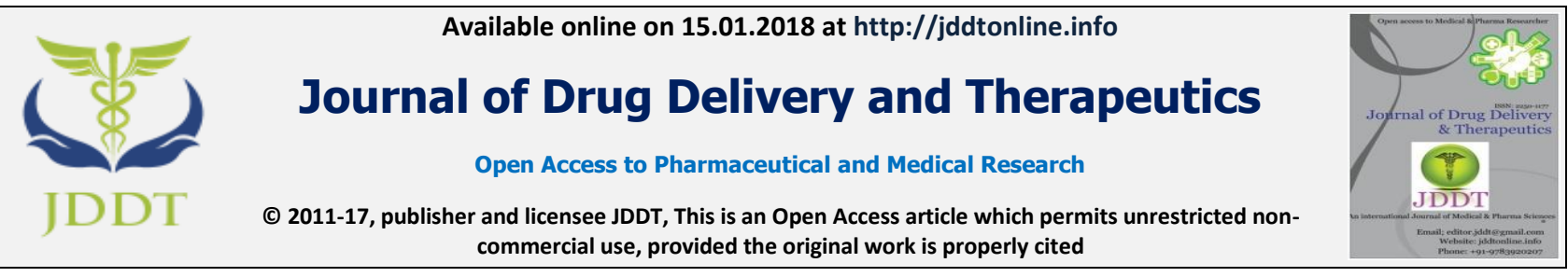

Open $\odot$ Access

Research Article

\title{
REACTIVE OXYGEN SPECIES AS POSSIBLE MEDIATOR OF ANTIBACTERIAL ACTIVITY OF PARKIA JAVANICA, AGAINST BACTERIAL SPECIES PREDOMINANTLY FOUND IN CHRONIC WOUND
}

\author{
Sil Samir Kumar ${ }^{1 *}$, Saha Susmita ${ }^{1}$ and Karmakar Parimal ${ }^{2}$ \\ ${ }^{1}$ Molecular Genetics and Cell Physiology Lab, Department of Human Physiology, Tripura University, Suryamaninagar, Tripura- \\ 799022, India \\ ${ }^{2}$ Department of Life Science and Biotechnology, Jadavpur University, 188, Raja S. C. Mallick Road, Kolkata, West Bengal-700032, \\ India.
}

\begin{abstract}
The crude methanol extract of Parkia javanica was screened for antibacterial activity. against bacterial species predominantly found in chronic wound, by serial dilution technique. Growth kinetics study was performed and percentage of ROS production was measured by NBT reduction assay. The minimum inhibitory concentration (MIC) and minimum bactericidal concentration (MBC) were obtained with a range of $\mathrm{IC}_{100} 5-40 \mathrm{mg} / \mathrm{ml}$ in case of standard bacterial strains. The lag phase of all extract treated bacteria is extended compared to untreated cells. The normalized $\%$ of ROS is increased in presence of crude extract. This study suggests that the crude methanol extract of Parkia javanica possesses promising antimicrobial substances which are having activity against Standard ATCC bacterial species and ROS induced DNA damage could be the possible mediator of its antimicrobial activity.
\end{abstract}

Keywords: Parkia javanica, antibacterial activity, standard ATCC bacterial strains, growth curve, ROS, DNA damage

Article Info: Received 26 Nov, 2017; Review Completed 04 Jan, 2018; Accepted 06 Jan, 2018; Available online 15 Jan, 2018

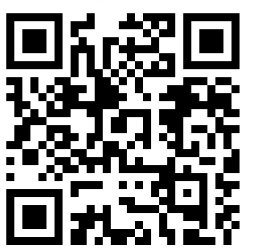

\section{Cite this article as:}

Sil SK, Saha S, Karmakar P, Reactive oxygen species as possible mediator of antibacterial activity of parkia javanica, against bacterial species predominantly found in chronic wound, Journal of Drug Delivery and Therapeutics. 2018; 8(1):43-45

DOI: http://dx.doi.org/10.22270/jddt.v8i1.1657

\section{*Address for Correspondence}

Sil Samir Kumar, Molecular Genetics and Cell Physiology Lab, Department of Human Physiology, Tripura University, Suryamaninagar, Tripura-799022, India, Email*: s_k_sil@yahoo.com

\section{INTRODUCTION}

Skin is the largest organ of our body, which protects us from various environmental factors ${ }^{1}$. Skin infections have become more common worldwide due to changes in the environmental conditions on the globe, as a hazardous result of industrialization, pollution, deforestation, etc ${ }^{2}$. So, we should concern ourselves, to protect this organ, as it is easily subjected to microbial attacks $^{3}$. Certain bacterial species, such as, Staphylococcus aureus, Streptococcus pyogens, Bacillus subtilis, Escherichia coli commonly occur in skin infection, even in the chronic skin wound of diabetic patients ${ }^{4}$. Different antibiotics produced by various pharmaceutical companies gradually becoming ineffective due to the emergence of resistance to these $\operatorname{drugs}^{5,6}$ and, as a result, the rate of morbidity and mortality has been increased due to bacterial infections ${ }^{7}$. So, it is an urge to identify new substances with effective antimicrobial activity, which can act as a source and template for the synthesis of new antimicrobial drugs. Plants have always been valuable source of antimicrobial agents ${ }^{8}$.

The plant, Parkia javanica is traditionally used as a food and ethno medicine by tribal population of Northeast India ${ }^{9}{ }^{10}$. In spite of having long ethno medicinal history, this plant has not been fully explored on scientific basis regarding its medicinal activities. The present work has been designed to understand 
antibacterial properties of this plant as well as possible mechanism of action using standard ATCC bacterial strains.

\section{MATERIALS AND METHODS}

\section{Plant collection \& Authentication}

Fresh stem barks of Parkia javanica were collected from Tripura, India. The plant was initially identified by Dr. B. K. Dutta, Taxonomist, Department of Botany, Tripura University and finally authenticated by Dr. H. J. Chowdhery, Joint Director, Central National Herbarium, Botanical Survey of India, Shibpur, Howrah, West Bengal and respective voucher specimen No. $\neq$ BD01/06 has been deposited in the Herbarium.

\section{Preparation Plant Extract}

Barks were cut into small pieces and allowed to dry in shade. Then $500 \mathrm{gm}$ of powdered bark was soaked in $2000 \mathrm{ml}$ of methanol to prepare the crude methanol extract of Parkia javanica (Crude MEPJ) and then kept in a shaker for 48 hours. After that the solution was filtered through Whatman filter paper no. 1 for 3 times. Then the solution was dried in rotary evaporator at $70^{\circ} \mathrm{C}$. Finally the solution was freeze- dried and stored at $-20^{\circ} \mathrm{C}^{11}$.

\section{Bacterial Culture and Growth Conditions}

Both standard gram negative bacterial species: Escherichia coli.(ATCC 11229), E. coli DH5a (MTCC 1652 India) artificially transformed with pUC19 plasmid and gram positive bacterial species: Staphylococcus aureus (NCTC 6571), Bacillus subtilis (ATCC 6633), Sreptococcus pyrogenes (ATCC 12384) were grown, cultured and maintained on Muller Hinton Broth. For long time storage $15 \%$ glycerol solution was used and vial was stored at $-80^{\circ} \mathrm{C}^{12}$.

\begin{tabular}{|c|c|c|}
\hline Determination of & Minimum & Inhibitory \\
\hline $\begin{array}{l}\text { Concentration (MIC) } \\
\text { Concentration (MBC) }\end{array}$ & and Minimum & Bactericidal \\
\hline
\end{tabular}

MIC was determined by serial dilution technique, with an inoculum of $10^{6} \mathrm{CFU} / \mathrm{ml}$ of both Gram positive and Gram negative standard bacterial strains in separate 96 well plates, in presence of increasing concentrations of crude MEPJ. The bacterial cultures were incubated at $37^{\circ} \mathrm{C}$ and shaken at $200 \mathrm{rpm}$ for 24 hours. Then the bacterial cell viability was determined by measuring the OD value at $600 \mathrm{~nm}$. Here, extract with media, used as blank; extract, media and bacterial culture, used as experiment; media with bacterial culture and $25 \%$ DMSO, used as positive control; and media with only $25 \%$ DMSO, used as negative control. Then, $\%$ of Inhibition was calculated by following formula,

\section{$\%$ of Inhibition $=[1-\{($ Exp. - Blank $) /($ Positive Control - Negative Control) $\}^{*}$ 100]}

Then MBC for each bacterial species were determined by treating the bacterial strains with 3 different doses, $\mathrm{IC}_{50}, \mathrm{IC}_{100}$ and $>\mathrm{IC}_{100}$ dose. After incubation with these 3 doses, one loop full bacterial culture from each tube was streaked on Muller Hinton agar plate in respective zone and again these plates were incubated at $37^{\circ} \mathrm{C}$ for overnight. $\mathrm{IC}_{100}$ value indicates the concentration which inhibits $100 \%$ of bacterial growth, whereas, MBC value indicates the concentration at which a drug can kill the bacterial species ${ }^{13}$.

\section{Measurement of Bacterial growth Kinetics}

To determine the bacterial growth kinetics, in presence of crude MEPJ, each bacterial species were grown in Muller Hinton Broth in presence and absence of extracts separately, at $37^{\circ} \mathrm{C}$ at $200 \mathrm{rpm}$ for 12 hours. Here, bacterial cells were treated with respective $\mathrm{IC}_{50}$ dose. Then, the bacterial concentration in presence and absence of extract were determined by measuring the OD at $600 \mathrm{~nm}$ in every 1 hour interval. Bacterial growth kinetics was plotted graphically with time versus $\mathrm{OD}_{600}{ }^{12}$.

\section{Estimation of Reactive Oxygen Species (ROS)}

$0.1 \mathrm{ml}$ of each bacterial suspension (where $\mathrm{OD}_{600}=1.0$ ) in Hank's balanced salt solution (HBSS) was incubated with respective $\mathrm{IC}_{50}$ dose of crude MEPJ for 2 hours with $15 \mathrm{~min}$ interval at $37^{\circ} \mathrm{C}$. Then $500 \mu \mathrm{l}$ of $1 \mathrm{mg} / \mathrm{ml}$ NBT was added and again incubated for $30 \mathrm{~min}$ at $37^{\circ} \mathrm{C}$. After incubation, $0.1(\mathrm{M}) \mathrm{HCl}$ was added and tubes were centrifuged at $3000 \mathrm{rpm}$ for $10 \mathrm{~min}$. The pellets were treated with $0.6 \mu \mathrm{l}$ of DMSO to extract the reduced NBT. Then, $0.5 \mu \mathrm{l}$ of HBSS was added and OD was measured at $575 \mathrm{~nm}$ (intracellular ROS) ${ }^{14}$.

\section{DNA damage Assay}

To examine the effect of crude MEPJ on DNA inside bacterial cell, reporter ( $\beta$-galactoside) gene expression assay was performed. In this assay, pUC19 transformed $\mathrm{DH} 5 \alpha$ cells were incubated for 3 hours at $37^{\circ} \mathrm{C}$ in presence or absence of $\mathrm{IC}_{50}$ dose of crude MEPJ. Then these bacterial cells were inoculated on Muller Hinton agar plate $\left(\mathrm{amp}^{+}\right)$containing X-gal and IPTG in medium and incubated for 12 hours at $37^{\circ} \mathrm{C}$ to observe the blue colour forming colonies ${ }^{14}$.

\section{Statistical Analysis}

We repeated these experiments for 3 times and data were expressed by calculating the standard deviation of all 3 experiments. ANOVA single factor (using Microsoft Office Excel) was used to determine statistical significance for multiple comparisons. $P<$ 0.05 was accepted as statistically significant.

\section{RESULTS}

\section{Determination of MIC:}

Antibacterial activity of crude MEPJ on Standard gram positive and gram negative bacterial species, was obtained by determining the minimum inhibitory concentrations. As shown in table 1, the growth of standard gram positive bacterial species, like B. subtilis and $S$. pyogenes were inhibited completely at lower concentrations of MEPJ $(5 \mathrm{mg} / \mathrm{ml})$, but growth of standard gram negative bacterial species $E$. coli and pUC19 plasmid transformed E. coli DH5 $\alpha$ were completely inhibited at too higher concentration of MEPJ (20 mg/ml and $40 \mathrm{mg} / \mathrm{ml}$ respectively). 
Table 1: MIC and MBC values of Standard bacterial Strains

\begin{tabular}{|c|c|c|c|}
\hline & $\mathbf{I C}_{\mathbf{1 0 0}}{ }^{*}$ & MBC* & MBC/MIC \\
\hline E. coli & $20 \pm 0.01$ & $20 \pm 0.05$ & 1.00 \\
\hline DH5 $\boldsymbol{\alpha}$ & $40 \pm 0.03$ & $40 \pm 0.01$ & 1.00 \\
\hline B. subtilis & $5 \pm 0.02$ & $5 \pm 0.08$ & 1.00 \\
\hline S. aureus & $10 \pm 0.05$ & $10 \pm 0.01$ & 1.00 \\
\hline S. pyogens & $5 \pm 0.04$ & $5 \pm 0.03$ & 1.00 \\
\hline
\end{tabular}

*Concentration of extracts in $\mathrm{mg} / \mathrm{ml}$. MIC: Minimum inhibitory concentration; MBC: Minimum bactericidal concentration; Experiments were performed in triplicate and all the MIC and MBC values are significant at the level of $p<$ 0.05 .

Minimum bactericidal concentration of crude MEPJ on each bacterial strain were also determined. According to Table 1 and Fig 1, the ratio between MBC and MIC for each bacterium is same ( $\sim$, for all bacteria). This result indicated that, crude MEPJ is a bactericidal agent rather than bacteriostatic agent.
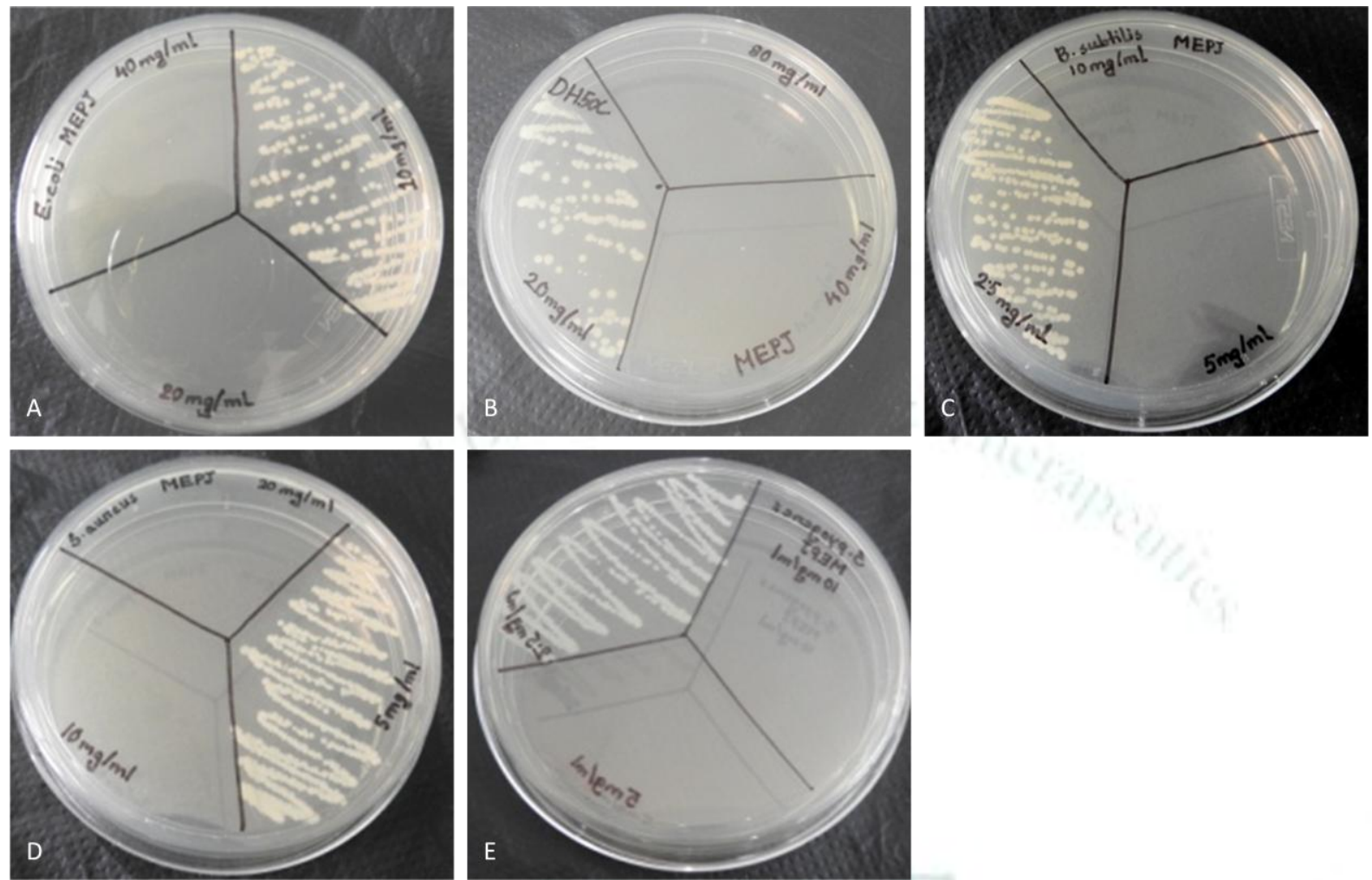

Figure 1: Muller Hinton agar plate showing the minimum bactericidal concentration (MBC) of MEPJ on standard ATCC strains of gram positive and gram negative bacterial species; (A) E. coli; (B) E. coli DH5a; (C) B. subtilis; (D) S. aureus; (E) S. pyogenes.

\section{Measurement of Bacterial Growth Kinetics:}

As crude MEPJ possess killing potential of different the bacterial species, so, we next measured the growth curve of both gram negative and gram positive standard bacterial strains to examine the pattern of the growth curve in presence and absence of crude MEPJ. All the bacterial strains were exposed to $P$. javanica extracts separately, at a concentration of $\mathrm{IC}_{50}$ dose for each bacterium. As shown in Fig 2, the lag phase of all crude MEPJ treated bacteria were extended compared to control. The growth of $S$. pyogens is mostly affected by the $P$. javanica extract.

\section{Estimation of ROS:}

Finally, to understand the mechanism of antibacterial activity of $P$. javanica, intracellular reactive oxygen species (ROS) were estimated after treatment with crude MEPJ at $\mathrm{IC}_{50}$ dose. As shown in Fig 3, after treatment of crude MEPJ, the production of ROS was increased drastically with time. It was highest in B. subtilis, in which ROS production increased about $70 \%$ in 3 hours compared to control, whereas in $\mathrm{DH} 5 \alpha$, ROS production increased about $35 \%$. The order of observed ROS production on 5 different bacterial strains were, $B$. Subtilis $>$ S. pyogenes $>$ S. aureus $>$ E. coli $>$ DH $5 \alpha$. 


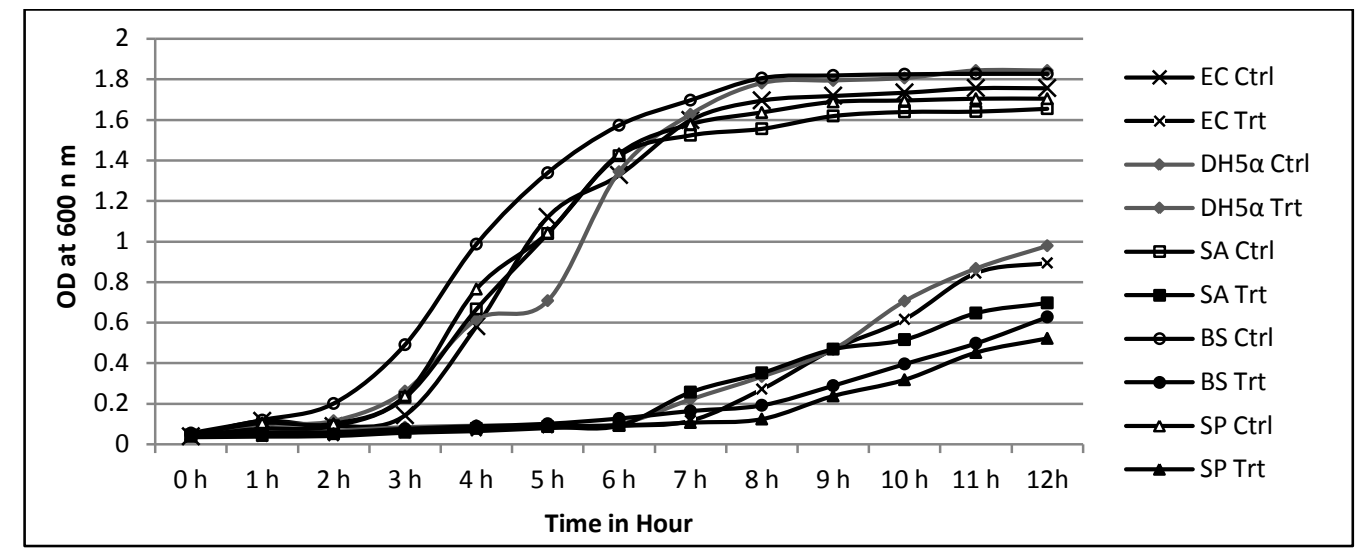

Figure 2: Effect of crude MEPJ at respective $\mathrm{IC}_{50}$ dose on pattern of growth curve of standard gram positive and gram negative bacterial strains; Ctrl: Control; Trt: treated with respective $\mathrm{IC}_{50}$ dose of MEPJ of each bacterium; EC: E. coli; DH5a: E. coli DH5a (Transformed bacteria); SA: Staphylococcus aureus; BS: Bacillus subtilis; SP: Streptococcus pyogenes.

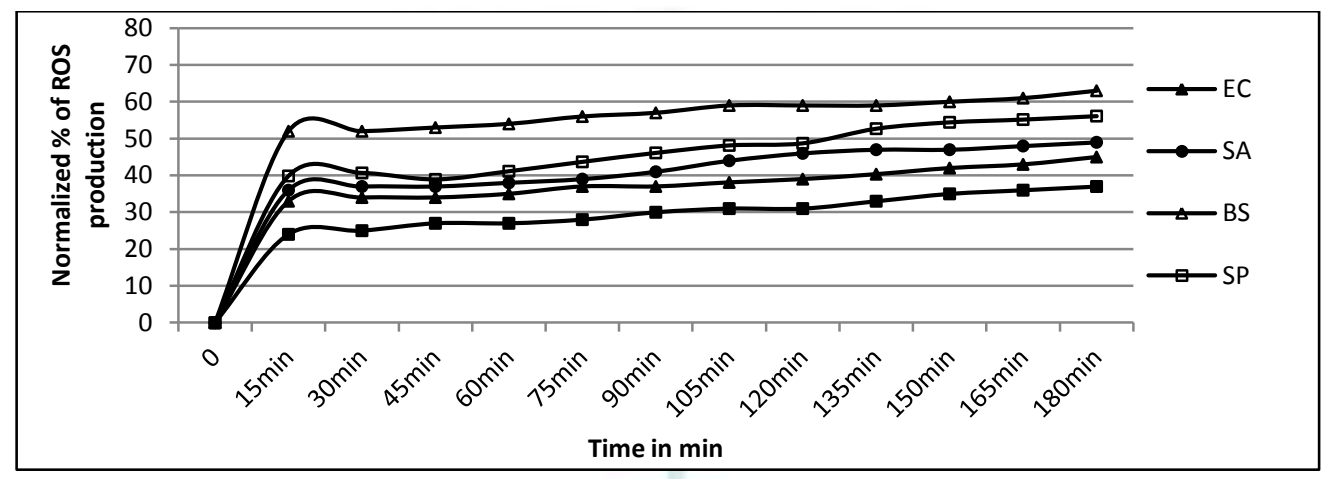

Figure 3: Effect of crude MEPJ at respective $\mathrm{IC}_{50}$ dose of each bacterium, on normalized \% of ROS production in standard gram positive and gram negative bacterial strains; EC: E. coli; DH5a: E. coli DH5a (Transformed bacteria); SA: Staphylococcus aureus; BS: Bacillus subtilis; SP: Streptococcus pyogenes.

DNA Damage assay:

As shown in Fig 3, ROS production was increased 35\% compared to control in E. coli DH5 $\alpha$. ROS usually targets the cellular DNA, so, to observe the effect of ROS inside bacterial cells, we used plasmid based reporter gene assay.

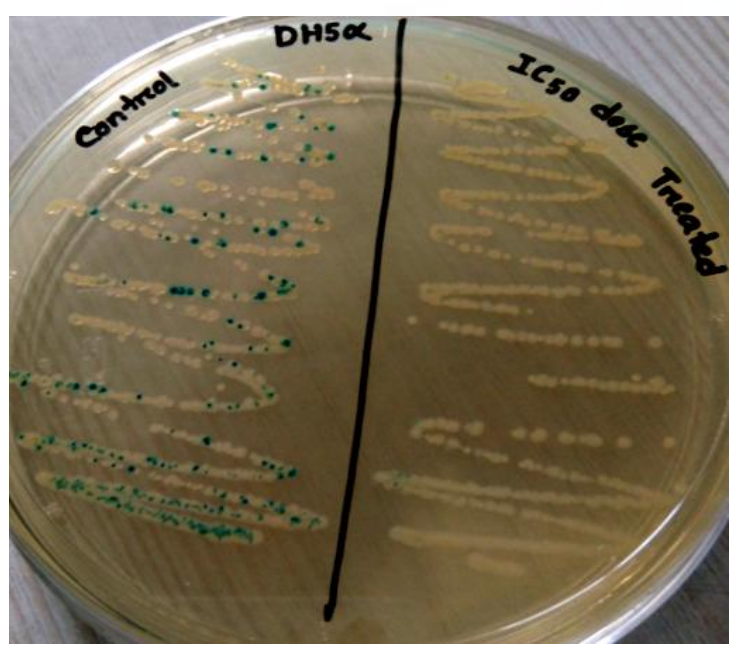

Figure 4: Reporter gene ( $\beta$-galactosidase) assay on pUC19 Transformed $E$. coli DH5 $\alpha$ treated with $\mathrm{IC}_{50}$ dose of MEPJ; Absence of blue colour colonies in treated cells indicates the DNA damage in tested bacteria.
In Fig 4 , reporter gene $\beta$-galactosidase was assayed by transforming the bacteria with the $p U C 19$ plasmid and then the bacterial cells were treated with crude MEPJ and chloroform fraction. The blue colonies, formed due to hydrolysis of $\mathrm{X}$-gal by $\beta$-galactosidase enzyme, were completely absent in case of bacterial cells treated with crude MEPJ.

\section{DISCUSSION}

Plants have been a cornerstone in traditional folk medicine to treat microbial infections and they also constitute sources of conventional antimicrobials ${ }^{15}$. In vitro evaluation of plants for antimicrobial properties is the first step towards achieving the goal for developing eco friendly management of infectious diseases ${ }^{16}$. In this study, Parkia javanica, a plant possessing an age old history of use as traditional folk medicine in Northeastern region of India, has been screened in vitro for antibacterial activity against five human bacterial species known to occur and aggravate the skin wound, even the chronic skin wound of diabetic patients.

Crude methanol extract showed antimicrobial activity against all the tested standard ATCC strains of gram positive (Staphylococcus aureus, Bacillus subtilis, Sreptococcus pyrogenes) and gram negative bacteria

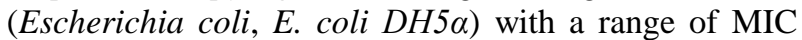
$\left(\mathrm{IC}_{100}\right)$ values. The two-fold serial dilution technique 
was used to determine the MIC values and it was observed that, the $\mathrm{IC}_{100}$ dose and $\mathrm{MBC}$, obtained using this technique are too less on some bacterial species. From growth kinetics study, it is found that, the lag phase of all extract treated bacteria is extended compared to untreated cells.

The same condition also observed in ROS production. The normalized \% of ROS is increased in presence of crude extract. Reactive by products of oxygen, such as superoxide anion radical (O2), hydrogen peroxide $(\mathrm{H} 2 \mathrm{O} 2)$, and the highly reactive hydroxyl radicals $(\cdot \mathrm{OH})$, are generated continuously in cells grown aerobically because these aerobic bacteria use molecular oxygen of nutrients to obtain energy ${ }^{17}$. These species cause damage to proteins, lipids, and nucleotides, negatively impacting the organism ${ }^{18}$. Living organisms operate mechanisms to protect themselves against oxidative stress, with enzymes such as catalase and superoxide dismutase, small proteins like thioredoxin and glutaredoxin, and molecules such as glutathione. However the damage ensues when the concentration of active oxygen increases to a level that exceeds the cell's defense capacity.

Absence of blue colour colonies after treatment in reporter gene assay indicates reporter pUC19 plasmid
DNA damage or mutation. Therefore, the active compound(s) present in $P$. javanica extract perhaps operated ROS induced DNA and other macro molecular damage to exert antibacterial activity. As $P$. javanica crude methanol extract can kill the variety of bacterial strains at lower concentrations, so, it may be a potent and cost effective source of antibacterial therapeutic agent(s).

\section{CONCLUSION}

In this study, we reported the antibacterial activity of crude methanol extract of $P$. javanica with their mode of action. The studies showed that, the crude extract was effective on variety of Gram negative and Gram positive bacterial standard strains. The ROS induced DNA damage is the possible mechanism of antibacterial activity of methanol extract of Parkia javanica.

\section{COFLICT OF INTERESTS}

The authors declare that there is no conflict of interests regarding the publication of this paper.

\section{ACKNOWLEDGEMENT}

We acknowledge State Biotech hub, Tripura University and Department of Biotechnology, Govt. of India for technical and financial support respectively.

\section{REFERENCES}

1. Sheipouri D, Braidy N, Guillemin GJ. Kynurenine pathway in skin cells: Implications for UV-induced skin damage. Int J Tryptophan Res 2012; 5:15-25.

2. Chaitanya SK, Hemanta KV, Sunitha RM. Activity of polyherbal extract against bacteria causing skin infections in diabetic patients. Asian J Pharm Clin Res 2017; 10(5):147149.

3. Anderson SE, Meade BJ. Potential health effects associated with dermal exposure to occupational chemicals. Environ Health Insights 2014; 8(1): 51-62.

4. Bader MS. Diabetic foot infection. Am Fam Physician 2008; 78(1):71-79.

5. Nascimento GGF, Locatelli J, Freitas PC, Silva GL. Antibacterial activity of plant extracts and phytochemicals on antibiotic resistant bacteria. Braz J of Microbio 2000; 31:247256.

6. Djeussi ED, Noumedem JAK, Seukep AJ, Fankam G A, Voukeng KI,Tankeo BS, Nkuete HLA and Kuete V. Antibacterial activities of selected edible plants extracts against multidrug-resistant gram-negative bacteria. BMC Compl and Alt Med 2013; 13:164.

7. Mattana CM, Satorres, SE, Escobar F, Sabini C, Sabini L, Fusco M, Alcaraz LE 2012. Antibacterial and cytotoxic activities of Acacia aroma extracts. Emir. J. Food Agric. 24(4):308-313.

8. Thamizhvanan K, Kumuda P, Nandakishore R. Antihelmintic and antimicrobial activity of petroleum ether extract of Yucca gloriosa L. whole plant. Int J Preclin Pharmceutical Res 2012; 3(1):20-22.

9. Sinha J. Medicinal plants of Manipur. Mass and Sinha Manipur Cultural Integration Conference. Imphal 2009.

10. Majumder K, Dutta BK, Roy D. Inventory and status of medicinal trees of Tripura. Ind Med Plant editor, P. C.

Trivedi. Avishkar publishers, Distributors. Jaipur 2009; pp 93- 123.

11. Bhardwaj S, Gakhar SK. Ethnomedicinal plants used by the tribals of Mizoram to cure cuts \& wounds. Ind J Trad knowledge 2005; 4(1): 75- 80.

12. Bhattacharya D, Samanta S, Mukherjee A, Santra CR, Ghosh AN, Niyogi SK, Karmakar P. Antibacterial Activities of Polyethylene Glycol, Tween 80 and Sodium Dodecyl Sulphate Coated Silver Nanoparticles in Normal and MultiDrug Resistant Bacteria. J Nanosci and Nanotech 2012; 12:1-9.

13. Demetrio LVJ, Jeannie IA, Juliana JMP, Esperanza CC. Antibacterial activities of ethanol extracts of Philippine medicinal plants against multidrug-resistant bacteria. Asian Pac J Trop Biomed 2015; 5(7):532-540.

14. Pramanik A, Laha D, Bhattacharya D, Pramanik P, Karmakar, P. A novel study of antibacterial activity of copper iodide nanoparticle mediated by DNA and membrane damage. Colloids and Surfaces B: Biointerfaces 2012; 96:50 55.

15. Gupta RN, Viswas K, Pathak M, Parihar SS, Gupta A. Antibacterial activities of ethanol extracts of plants used in folk medicine. Int J Res Ayur Pharm 2010; 1(2); 529-535.

16. Kumar S, Nancy, Singh D, Kumar V. Evaluating the antibacterial activity of plant extracts against bacterial pathogens. J Drug Delivery Therapeutics 2012; 2(4); 182185.

17. Cabiscol E, Tamarit J, Ros J. Oxidative stress in bacteria and protein damage by reactive oxygen species. Int. Microbiol 2000; 3:3-8.

18. De Orue Lucana DO, Wedderhoff I, Groves MR. ROS mediated signalling in bacteria: zinc-containing cys- $\mathrm{X}-\mathrm{X}$-cys redox centres and iron based oxidative stress. J Sig Trans 2012; doi: 10.1155/2012/605905. 